\title{
Effect of Foliar Nutrition on Uptake of Nutrients and Economics of Soybean
}

\author{
Indrapal Singh Paikra*, R. Lakpale, Paramjeet Singh and Vijay Kumar
}

Indira Gandhi Krishi Vishwavidyalaya, College of Agriculture, Raipur, Chhattisgarh (492 012), India

\author{
Corresponding Author \\ Indrapal Singh Paikra \\ e-mail: indrapaikra005@gmail.com
}

\author{
Article History \\ Article ID: $3 \mathrm{C0765}$ \\ Received in $29^{\text {th }}$ October, 2017 \\ Received in revised form $29^{\text {th }}$ April, 2018 \\ Accepted in final form $25^{\text {th }}$ May, 2018
}

\begin{abstract}
A field experiment was conducted during kharif season of 2015 at the Research cum Instructional Farm, Indira Gandhi Krishi Vishwavidyalaya, Raipur to evaluate the effect of foliar nutrition on uptake of nutrients and economics of Soybean [Glycine max (L.) Merrill] under Vertisols of Chhattisgarh plains. The experiment was laid out in Randomized Block Design with three replications. The results revealed that application of RDF+spray of DAP @ 2\% at pod initiations stages of crop growth resulted significantly higher uptake of nutrients N, P, K, and also positive effect on micronutrients and economics compared to the application of RDF+Water spray at pod initiation stage and RDF only. It also positive effect on micronutrients in soil such as activity of microbial population, improve seed quality and oil quality of soybean through regulate nutrient during pod filling stage when the soil are not able to provide nutrients, quality parameters and nutrient uptake of soybean were significantly influenced by foliar application of nutrients at different stages of crop. The foliar application of RDF+spray of DAP @ $2 \%$ recorded significantly higher net return of ₹ 60,279 with. B:C ratio of 3.07 . Foliar spraying with $2 \%$ DAP at flowering and at early pod development in addition to soil application of NPK fertilizer was found to be more beneficial to improve the productivity of soybean than RDF application alone.
\end{abstract}

Keywords: Soybean, foliar spray, micronutrients, quality

\section{Introduction}

Soybean is a cheapest source of vegetable oil as well as protein. It contains about $40 \%$ protein, well balanced in essential amino acids, $20 \%$ oil rich with poly unsaturated fatty acids specially Omega 6 and Omega 3 fatty acids, $6-7 \%$ total mineral, $5-6 \%$ crude fiber and $17-19 \%$ carbohydrates. The protein quality of soybean is equivalent to that of meat, milk products and eggs. It is generally grown as a rainy season crop under rainfed situation. Thus, it is a "miracle bean" having many advantages. Soybean is recognized as golden bean because of its high nutritional values and economic importance. Soybean [Glycine max (L.) Merrill] is one of the most important oilseed crops in the world and it is also wonder crop of the twentieth century. The crop also helps in increasing the fertility level of soil through symbiotic nitrogen fixation. Foliar spraying is one alternative approach through micro nutrients are made to crop in liquid form through foliage (Nasiri et al., 2010). Foliar application of microelements is more beneficial than soil application. Since application rates are lesser as compared to soil application, same application could be obtained easily and crop reacts to nutrient application immediately (Zayed et al., 2011). Foliar spraying of microelements is very helpful when the roots cannot provide essential micro nutrients to the crop (Kinaci and Gulmezoglu, 2007). Moreover, soil pollution would be a major problem by micronutrients soil application. As people are concerned about the environment, foliar sprays of nutrients are better than soil application (Bozorgi et al., 2011).

Foliar application of macro and micro nutrients was more beneficial to legumes (Zayed et al., 2011). However adequate information on the effect of foliar application of Nitrogen, Phosphorus, Potassium, Molybdenum, Boron and Zinc on soybean was not available in Chhattisgarh agro-climatic condition. Considering above state facts, it has been proposed to study the effect of foliar nutrition of Nitrogen, Phosphorus, Potassium, Molybdenum, Boron and Zinc on growth and yield of soybean. Keeping the above fact in mind, the present investigation entitled" Effect of Foliar Nutrition on uptake of Nutrients and Economics of Soybean [Glycine max (L.) Merrill]

\section{Materials and Methods}

A field experiment was conducted during kharif season of 2015 at the Research cum Instructional Farm, Indira Gandhi Krishi Vishwavidyalaya, Raipur to evaluate the Effect of foliar nutrition on uptake of nutrients and economics of soybean [Glycine max (L.) Merril] under Vertisols of Chhattisgarh 
plains. The soil was clayey in nature, neutral in $\mathrm{pH}$ and had low nitrogen, medium phosphorus and high in potassium content. The experiment was laid out in Randomized Block Design with three replications. The treatments were allotted in field follow the random methods. The nine treatments consisted of various combination of nutrition application of RDF+Water spray at pod initiation, RDF + Urea $2 \%$ spray at pod initiation RDF+DAP 2\% spray at pod initiation, RDF+MOP $0.5 \%$ at pod initiation, RDF+NPK (19:19:19) $2 \%$ at pod initiation, RDF+Molybdenum $0.5 \%$ at pod initiation, RDF+Boron $0.5 \%$ at pod initiation, RDF+Zinc Chelated $0.5 \%$ at pod initiation, RDF alone. Recommended dose of fertilizer applied as basal dose and micronutrients applied as foliar spray at pod initiation stage.

\section{Results and Discussion}

\subsection{Nutrient uptake or concentration (\%)}

Foliar application of RDF+ spray of DAP @ 2\% at pod initiation stage recorded highest nutrient uptake of soybean. This might be due to the application of micronutrients in the form of foliar spray responded well and might be helpful to absorb other nutrients also in balance amount resulted more concentration of $\mathrm{N}, \mathrm{P}, \mathrm{K}, \mathrm{Mo}, \mathrm{B}$ and zinc in plant also reported by (Mittra et al., 1987) (Table 1 and 2). Foliar application of RDF+spray of

Table 1: Nutrient uptake and concentration (\%) of soybean as affected by different treatments of micronutrients

\begin{tabular}{lcccccc}
\hline \multirow{2}{*}{ Treatments } & \multicolumn{6}{c}{ Nutrient uptake by plants } \\
\cline { 2 - 7 } & $\mathrm{N}$ & $\mathrm{P}_{2} \mathrm{O}_{5}$ & $\mathrm{~K}_{2} \mathrm{O}$ & $\mathrm{Mo}$ & $\mathrm{B}$ & $\mathrm{Zn}$ \\
\hline $\mathrm{T}_{1}$ & 184.6 & 26.00 & 113.8 & 0.02 & 0.02 & 0.02 \\
$\mathrm{~T}_{2}$ & 185.8 & 28.00 & 115.6 & 0.12 & 0.02 & 0.03 \\
$\mathrm{~T}_{3}$ & 190.1 & 30.00 & 117.2 & 0.04 & 0.03 & 0.04 \\
$\mathrm{~T}_{4}$ & 185.3 & 28.00 & 116.0 & 0.03 & 0.02 & 0.03 \\
$\mathrm{~T}_{5}$ & 185.1 & 28.00 & 115.5 & 0.02 & 0.02 & 0.02 \\
$\mathrm{~T}_{6}$ & 184.5 & 26.00 & 115.1 & 0.04 & 0.03 & 0.03 \\
$\mathrm{~T}_{7}$ & 184.8 & 28.00 & 114.6 & 0.02 & 0.05 & 0.02 \\
$\mathrm{~T}_{8}$ & 184.5 & 28.00 & 114.4 & 0.02 & 0.02 & 0.14 \\
$\mathrm{~T}_{9}$ & 184.2 & 26.00 & 113.5 & 0.02 & 0.02 & 0.02 \\
$\mathrm{SEm} \pm$ & 1.548 & 0.354 & 0.522 & 0.032 & 0.011 & 0.041 \\
$\mathrm{CD}(p=0.05)$ & 4.641 & 1.062 & 1.565 & $\mathrm{NS}$ & $\mathrm{NS}$ & $\mathrm{NS}$ \\
\hline $\mathrm{N}$ & & & &
\end{tabular}

$\mathrm{N}$ : N $\left(\mathrm{kg} \mathrm{ha}^{-1}\right)$ Stover; $\mathrm{P}_{2} \mathrm{O}_{5}: \mathrm{P}_{2} \mathrm{O}_{5}: \mathrm{P}_{2} \mathrm{O}_{5}\left(\mathrm{~kg} \mathrm{ha}^{-1}\right)$ Stover; $\mathrm{K}_{2} \mathrm{O}$ : $\mathrm{K}_{2} \mathrm{O}\left(\mathrm{kg} \mathrm{ha}^{-1}\right)$ stover; Mo: Mo $\left(\mathrm{Mg} \mathrm{kg}^{-1}\right)$ Stover; B: B (Mg kg$\left.{ }^{1}\right)$ Stover; Zn: Zn (Mg kg-1) stover; $T_{1}$ : RDF+Water spray at pod initiation; $\mathrm{T}_{2}$ : RDF+Urea $2 \%$ spray at pod initiation; $\mathrm{T}_{3}$ : RDF+DAP $2 \%$ spray at pod initiation; $T_{4}$ : RDF+MOP $0.5 \%$ at pod initiation; $T_{5}$ : RDF+19:19:19 (NPK) 2\% at pod initiation; $\mathrm{T}_{6}: \mathrm{RDF}+$ Molybdenum $0.5 \%$ at pod initiation; $\mathrm{T}_{7}: \mathrm{RDF}+$ Boron $0.5 \%$ at pod initiation; $T_{8}:$ RDF+Zinc Chelated $0.5 \%$ at pod initiation; $T_{9}$ : RDF only
Table 2: Balance sheet of available soil nitrogen as influenced by foliar spray of micronutrients

\begin{tabular}{llllllll}
\hline $\begin{array}{l}\text { Treat- } \\
\text { ments }\end{array}$ & ISS & NA & TNU & ENB & BANAHA & AG & BUDA \\
\hline $\mathrm{T}_{1}$ & 210 & 30 & 184.6 & 55.4 & 220 & 164.6 & 10 \\
$\mathrm{~T}_{2}$ & 210 & 30 & 185.8 & 54.2 & 219 & 164.9 & 9.1 \\
$\mathrm{~T}_{3}$ & 210 & 30 & 195.1 & 44.9 & 218 & 173.4 & 8.3 \\
$\mathrm{~T}_{4}$ & 210 & 30 & 185.3 & 54.7 & 217 & 162.8 & 7.5 \\
$\mathrm{~T}_{5}$ & 210 & 30 & 185.1 & 54.9 & 215 & 162.2 & 7.1 \\
$\mathrm{~T}_{6}$ & 210 & 30 & 184.5 & 55.5 & 216 & 159.8 & 5.3 \\
$\mathrm{~T}_{7}$ & 210 & 30 & 184.8 & 55.2 & 215 & 160.1 & 5.3 \\
$\mathrm{~T}_{8}$ & 210 & 30 & 184.5 & 55.5 & 215 & 159.5 & 5 \\
$\mathrm{~T}_{9}$ & 210 & 30 & 184.2 & 55.8 & 215 & 159.6 & 5.4 \\
\hline
\end{tabular}

ISS: initial soil status ( $\left.\mathrm{kg} \mathrm{ha}^{-1}\right)$; NA: Nutrient added $\left(\mathrm{kg} \mathrm{ha}^{-1}\right)$; TNU: Total nutrient uptake ( $\left.\mathrm{kg} \mathrm{ha}^{-1}\right)$; ENB: Expected nutrient balance ( $\mathrm{kg} \mathrm{ha}^{-1}$ ); BANAHA: Balance of available $\mathrm{N}$ after harvest Applied gain/loss; AG: Apparent gain/loss ( $\left.\mathrm{kg} \mathrm{ha}^{-1}\right)$; BUDA: Build up (+) or depletion (-) of available $\mathrm{N}\left(\mathrm{kg} \mathrm{ha}^{-1}\right)$

DAP @ $2 \%$ at pod initiation Nutrient uptake or concentration (\%) of soybean recorded highest The maximum build up of nutrients it might be due to through the high activity of root nodules which help the atmospheric nitrogen fixation which turn increases the nutrient status of the soil and also positive response to $P, K$, and micronutrients.

Maximum gross return, net return and benefit: cost ratio was recorded under application of RDF+spray of DAP @ 2\% in soybean (Table 3). The increase in gross and net return is obviously due to higher seed yield. Less input cost and higher economical yield might be resultant in increase the B: C ratio. Similar result was also reported by (Kumar et al., 2013) spray of DAP @ 2\% twice at flower initiation and pod formation stages of crop growth recorded higher gross returns

Table 3: Balance sheet of available soil phosphorus as influenced by foliar spray of micronutrients

\begin{tabular}{lccccccc}
\hline $\begin{array}{l}\text { Treat- } \\
\text { ments }\end{array}$ & ISS & NA & TNU & ENB & BANAHA & AG & BUDA \\
\hline $\mathrm{T}_{1}$ & 16.4 & 60 & 26 & 50.4 & 40.3 & 10.0 & 23.9 \\
$\mathrm{~T}_{2}$ & 16.4 & 60 & 28 & 48.4 & 42.7 & 5.7 & 26.3 \\
$\mathrm{~T}_{3}$ & 16.4 & 60 & 30 & 46.4 & 43.9 & 2.5 & 27.5 \\
$\mathrm{~T}_{4}$ & 16.4 & 60 & 28 & 48.4 & 42.6 & 5.8 & 26.2 \\
$\mathrm{~T}_{5}$ & 16.4 & 60 & 28 & 48.4 & 44.9 & 3.5 & 28.5 \\
$\mathrm{~T}_{6}$ & 16.4 & 60 & 26 & 50.4 & 46.9 & 3.5 & 30.5 \\
$\mathrm{~T}_{7}$ & 16.4 & 60 & 28 & 48.4 & 42.7 & 5.7 & 26.3 \\
$\mathrm{~T}_{8}$ & 16.4 & 60 & 28 & 48.4 & 42.9 & 5.5 & 26.5 \\
$\mathrm{~T}_{9}$ & 16.4 & 60 & 26 & 50.4 & 44.0 & 6.4 & 27.6 \\
\hline
\end{tabular}


(₹ 36,500) and net returns ( $₹ 20,090$ ) followed by foliar spray of local variety at flower initiation and pod formation stages of crop growth with gross returns of ₹ 33,125 and net returns of Rs. 15,675. Water spray recorded the least gross returns ( $₹$
$20,250)$ and net returns $(₹ 4,000)$, and the $B: C$ ratio $(2.22)$ was higher under the treatments where DAP @ 2\% was applied twice at flower initiation and pod formation stages of crop growth (Table 4 and 5).

\begin{tabular}{lccccccc}
\hline \multicolumn{6}{l}{ Table 4: Balance sheet of available soil potash as influenced by foliar spray of micronutrients } \\
\hline Treatments & $\begin{array}{c}\text { initial soil } \\
\text { status } \\
\left(\mathrm{kg} \mathrm{ha}^{-1}\right)\end{array}$ & $\begin{array}{c}\text { Nutrient } \\
\text { added } \\
\left(\mathrm{kg} \mathrm{ha}^{-1}\right)\end{array}$ & $\begin{array}{c}\text { Total Nutri- } \\
\text { ent uptake } \\
\left(\mathrm{kg} \mathrm{ha}^{-1}\right)\end{array}$ & $\begin{array}{c}\text { Expected nu- } \\
\text { trient balance } \\
\left(\mathrm{kg} \mathrm{ha}^{-1}\right)\end{array}$ & $\begin{array}{c}\text { Balance of available } \\
\text { Nafter harvest Ap- } \\
\text { plied gain/loss }\end{array}$ & $\begin{array}{c}\text { Apparent } \\
\text { gain/ loss } \\
\left(\mathrm{kg} \mathrm{ha}^{-1}\right)\end{array}$ & $\begin{array}{c}\text { Build up (+) or } \\
\text { depletion }(-) \\
\text { available } \mathrm{N}\left(\mathrm{kg} \mathrm{ha}^{-1}\right)\end{array}$ \\
\hline $\mathrm{T}_{1}$ & 330 & 30 & 113.8 & 246.2 & 340.6 & 94.4 & 10.6 \\
$\mathrm{~T}_{2}$ & 330 & 30 & 115.6 & 244.4 & 337.5 & 93.1 & 7.5 \\
$\mathrm{~T}_{3}$ & 330 & 30 & 117.2 & 242.3 & 336.1 & 93.8 & 6.1 \\
$\mathrm{~T}_{4}$ & 330 & 30 & 116.0 & 244.0 & 338.0 & 94.8 & 8.8 \\
$\mathrm{~T}_{5}$ & 330 & 30 & 115.5 & 244.5 & 339.0 & 94.5 & 9.0 \\
$\mathrm{~T}_{6}$ & 330 & 30 & 115.1 & 244.9 & 337.0 & 92.6 & 7.5 \\
$\mathrm{~T}_{7}$ & 330 & 30 & 114.4 & 245.6 & 338.0 & 93.0 & 8.6 \\
$\mathrm{~T}_{8}$ & 330 & 30 & 114.0 & 245.6 & 339.0 & 93.9 & 9.5 \\
$\mathrm{~T}_{9}$ & 330 & 30 & 113.5 & 246.5 & 336.0 & 90.0 & 6.5
\end{tabular}

Table 5: Economics of soybean as affected by different treatments of micronutrients

\begin{tabular}{lcccc}
\hline Treatments & $\begin{array}{c}\text { Cost of } \\
\text { cultivation } \\
\left(₹ \text { ha }^{-1}\right)\end{array}$ & $\begin{array}{c}\text { Gross } \\
\text { return } \\
\left(₹ \text { ha }{ }^{-1}\right)\end{array}$ & $\begin{array}{c}\text { Net return } \\
\left(₹ \text { ha }{ }^{-1}\right)\end{array}$ & $\begin{array}{c}\mathrm{B}: \mathrm{C} \\
\text { ratio }\end{array}$ \\
\hline $\mathrm{T}_{1}$ & 19382 & 75445 & 56063 & 2.89 \\
$\mathrm{~T}_{2}$ & 19452 & 77634 & 58182 & 2.99 \\
$\mathrm{~T}_{3}$ & 19632 & 79911 & 60279 & 3.07 \\
$\mathrm{~T}_{4}$ & 19427 & 78071 & 58644 & 3.02 \\
$\mathrm{~T}_{5}$ & 21632 & 75570 & 53938 & 2.49 \\
$\mathrm{~T}_{6}$ & 34382 & 67335 & 32953 & 0.96 \\
$\mathrm{~T}_{7}$ & 20922 & 72945 & 52023 & 2.49 \\
$\mathrm{~T}_{8}$ & 21227 & 73655 & 52428 & 2.47 \\
$\mathrm{~T}_{9}$ & 19182 & 71497 & 52315 & 2.73 \\
$\mathrm{SEm} \pm$ & - & 2006 & 2006 & 0.098 \\
$\mathrm{CD}(p=0.05)$ & - & NS & NS & NS \\
\hline
\end{tabular}

\section{Conclusion}

Foliar spray of DAP @ 2\% higher uptake of nutrients by plants and positive effect on yield and also registered significantly higher net return of (₹ 60,279 ) with $B: C$ ratio of 3.07 . When compared with the application of RDF only.

\section{References}

Bozorgi, H.A., Azarpour, E., Moradi, M., 2011. Effects of bio, mineral nitrogen fertilization and foliar zinc spraying on yield and yield components of faba bean. World Applied Sciences Journal 13(6), 1409-1414.
Ganapathy, M., Baradhan, G., Ramesh, N., 2008. Effect of foliar nutrition on reproductive efficiency and grain yield of rice fallow pulses. Legume Research 31, 142-144.

Kumar, S., Basavarajappa, R., Salakinkop, S.R., Hebbar, M., Basavarajappa, M.P., Patil, H.Y., 2013a. Influence of foliar nutrition on performance of blackgram (Vigna mungo L.). Nutrient Uptake and Economics under Dry Land Ecosystems Legume Research 36(5), 422-428.

Kumar, C.V., Vaiyapuri, K., Amanullah, M.M., Gopalaswamy, G., 2013b. Influence of foliar spray of nutrients on yield and economics of soybean (Glycine max L. Merill). journal of biological sciences 13(6), 563-565.

Kinaci, E., Gulmezoglu, N., 2007. Grain yield and yield components of triticale upon application of different foliar fertilizers. Interciencia 32(9), 624-628.

Mitra, R., Pawar, S.E., Bhatia, C.R., 1987. Effect of foliar spray of nutrients and plant growth regulators (PGRs) for yield maximization in blackgram. International Symposium, Bangkok, Thailand 16-20. AVRDC (Tropical Vegetable Information Service), 244-251.

Nasiri, Y., Zehtab-Salmasi, S., Nasrullahzadeh, S., Najafi, N., Ghassemi, K., 2010. Effects of foliar application of micronutrients (Fe and $\mathrm{Zn}$ ) on flower yield and essential oil of chamomile (Matricaria chamomilla L.). Journal of Medicinal Plants Research 4(17), 1733-1737.

Yakadri, M., Ramesh, T., 2002. Effect of soil application of potassium and DAP spray in blackgram (Vigna mungo L.). Madras Agricultural Journal 89, 147-149.

Zayed, A., Salem, M., Sharkawy, M., 2011. Effect of different micronutrient treatments on rice (Oriza sativa L.) growth and yield under saline soil conditions. World Journal of Agricultural Sciences 7(2), 179-184. 